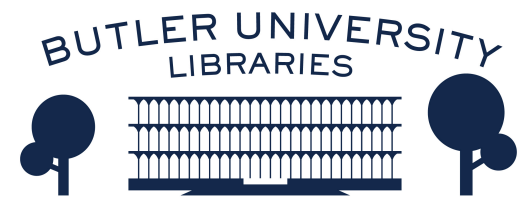

Journal of Hindu-Christian Studies

Volume 4

Article 8

January 1991

\title{
Viewpoints: Art and Architecture as Locus for Dialogue: The Holy Place as a Common Ground for Dialogue
}

Jyoti Sahi

Follow this and additional works at: https://digitalcommons.butler.edu/jhcs

Part of the Religion Commons

\section{Recommended Citation}

Sahi, Jyoti (1991) "Viewpoints: Art and Architecture as Locus for Dialogue: The Holy Place as a Common Ground for Dialogue," Journal of Hindu-Christian Studies: Vol. 4, Article 8.

Available at: https://doi.org/10.7825/2164-6279.1046

The Journal of Hindu-Christian Studies is a publication of the Society for Hindu-Christian Studies. The digital version is made available by Digital Commons @ Butler University. For questions about the Journal or the Society, please contact cbauman@butler.edu. For more information about Digital Commons @ Butler University, please contact digitalscholarship@butler.edu. 


\title{
The Holy Place as a Common Ground for Dialogue
}

\author{
Jyoti Sahi \\ Indian School for Art and Peace \\ Silvepura Turbana halli, Bangalore 560090 India
}

\begin{abstract}
THIS yeAR HAS been in many ways deeply distressing. Sadam Hussein, while preparing the way, along with the various hawks of the West, for a confrontation of armed forces reminiscent of an apocalyptic armageddon, has looked forward to a time when he and Arafat can pray together in the Holy city of Jerusalem. Meanwhile on the banks of the River Ganges Hindus and Muslims have laid claims to a plot of land which for different reasons each holds to be sacred. The confrontation threatens to tear Indian spiritual unity apart, setting person against person in bloody conflict.

Recently whilst visiting the holy city of Varanasi, I was struck again by the living tradition of spirituality rooted so much in nature - the flowing river, the cycle of festivals which commemorate the seasons. Amāvāsyã, the dark of the moon, had just been celebrated with ritual bathing, and down by the ghats the Bengali craftsmen were preparing clay images of Sarasvati, the Goddess of Wisdom, who is also like a hidden stream, for final emersion in the Sacred River after "Saraswati Pūjâ."

In 1989, at a meeting in Rome organized by SEDOS, the theme of popular spirituality was discussed. It had been pointed out that spirituality is not the monopoly of the refined and philosophical elite, but is to be experienced in the popular myths and festivals of ordinary simple people. Central to this cosmic Religion of Tribals or peasants (what we might call "folk religion") is a sense of the sacred in the world-the Holy River, flowing through a promised land. The so-called meta-cosmic or philosophical world-view has tended to claim for itself to be the spirituality, everything else
\end{abstract}

being relegated to the status of being merely "superstition", born of ignorance. But standing on the ghats of Varanasi and watching pilgrims coming from villages all over India, one cannot but be impressed by their simple faith and piety. But yet one is also aware that this popular spirituality can also be easily manipulated by political forces so that this cheerful sadhu sitting by the river, exuding a really genuine friendship and sense of universal brotherhood, might easily be aroused by a brand of politically motivated rhetoric, to really terrible acts of violence against people of another faith. It is the proximity of this popular religiosity to a kind of religious fundamentalism which is so disturbing a factor of the modern world situation.

As an artist I have been concerned with the symbols of this cosmic faith which forms the basis for what we might call a popular spirituality. These symbols, which arise from a close involvement in nature, are expressive of a deep sense of the sacredness of the land. It is from this symbolic worldview that the temple cult has slowly emerged. There is a universality underlying the image of the temple. I have remarked on the fact that reading the description of the Temple in Ezekiel, one could easily imagine that it refers to an architectural form very reminiscent of one of India's great temple cities, such as we find for example in Madurai. Those who have studied the gradual evolution of the Indian Temple, like Stella Kramrich, have pointed out the possible influence of Babylonian or Central Asian Prototypes. Even further back there are sacred structures belonging to the late stone age to be found in Neolythic India; but also in Celtic Eu- 
Journal of Hindu-Christian Studies, Vol. 4 [1991], Art. 8

36 Viewpoints

rope - which also follow a basic pattern, in that case based on the primordial stone circle. These have been extensively studied by such scholars as Ferguson, whose book on the subject was entitled "Rude Stone Monuments". The characteristic forms of the Buddhist Stupa seem to derive from these neolythic prototypes. We have, therefore, two basic archetypes: the stone circle, leading ultimately to the domed structure symbolizing the rounded cosmos, or the sacred square, surmounted by the pyramidical super structure, meant to symbolize the holy mountain, or axis of the universe.

Such symbols are rooted in a belief that every part of the earth is holy, but that certain sacred places become focal points in the landscape, associated with the basic assumption that the microcosm reflects the macrocosm. These focal points are experienced by a whole community as "hierophanies", that is sacred events where a revelation of the Divine Power becomes manifest.

The question whether or not Ayodhya, for example, is the actual place where Rama was born, is of course not the kind of question a simple believer bothers to ask. For a pious pilgrim issues such as historical verifiability are non-issues. No sacred place can be explained or justified in this sort of way. Is the Church of the Holy Sepulchre on the exact place where Jesus rose from the dead? Is the Church of the Nativity in Nazareth actually built where Jesus was born? Such problems become purely academic - the strange acretions of an empirical, rational mind-set which has nothing to do with the rock bed of devotion. In that sense secular, historical criteria have absolutely no authority in the field of popular devotions.

But, from this it does not simply follow that there is no sense of meaning in what we are calling popular spirituality. As has been discovered by those who have made a deep study of the symbol systems underlying folk spirituality, there is a very powerful integrity in the whole pattern of thought that finally leads to the emergence of a sacred place. A sense of the sacredness of some particular site is not historically determined, but it does appear out of clearly definable social needs and expectations. It is clear that a community needs a focus and the sense of a divine mandate-but this arises almost out of a community dream, and can even be articulated through a mystical vision, rather than some empirically definable rationale. If some Hindu monk had claimed to have had a "vision" of Lord Răma at Ayodhya, this would have held as much spiritual weight as any amount of archaeological proof concerning the authenticity of a certain site, in its claim to being the birth place of the Lord Răma.

But can "holy places" be created? In other words can a sense of the sacred be manipulated by those who want, for one reason or another, to give a community a focus for that vast undifferentiated world of inner longing and potentiality for religious devotion?

As a person involved in the designing of Temples, or places of worship, I have felt drawn to Holy places wherever they appear. I have "felt" the presence of a power in certain Holy Sites - and also the absence of that power in other places of worship. Walking up the hill from the Ashram of Rāmana Maharishi to Skanda Ashram on Arunachalam, the sense of the sacredness of this hill is almost tangible. But then a hill like this was probably the focus of a popular cult going back to pre-historic times. Different faiths may come and go-Jain, Buddhist, Hindu phases of Indian culture may rise and fall but still probably this mountain was held to be a holy place by everyone. In a sense a holy place transcends all religious formulations. A good example of that is Jerusalem itself. This holy city has been the focus of veneration and an eschatological hope for Jews, Christians and Muslims alike. The fact that Jerusalem the Holy place stands above the various religions which have attempted to appropriate her is both her greatness and her tragedy.

In fact missionary movements have made it a policy to take possession of sacred places, then to claim them as their own, in that way controlling the deeper, ground swell, so to say, of popular emotion, and attachment to the land. Thus Christians have very consciously built churches on earlier sacred sites, thus "baptizing", an earlier more archaic devotion. Many of the great churches of Europe are built on sites which were holy long before they were Christian. The same is true of Muslim holy 
places-and also Brahmanic ones. It is a well known fact that there is a process of Sanskritization and appropriation by the so-called "Great tradition" of ancient Tribal holy places in India. In Karnataka, for example, I have visited a holy place called Bili Rangana Betta, which has been a cultic focus for a tribe called the Solegars. Here on a mountain in the Nilgiri range of hills, a goddess of the tribals is worshipped. But during the Vaișnava expansion, following the influx of Tamil Iycngars into Karnataka, when the grat mystic and philosopher Ramanuja emigrated to this state, a number of local deities were taken over by the newly born bhakti movement. Thus the tribal goddess of the Solegars was "married" to Lord Ranganath, a manifestation of Siva. This tendency of marrying some great deity of the Brahmanic Schools - Śiva or Visnu - to certain local, or tribal deities, is an example of how a cosmic, popular earth goddess was taken over by the more philosophic religious movements of Brahmanism. This was naturally followed by the local tribal, or lowcaste priesthood being displaced by Brahmins who took over the popular cult. The same pattern can be found in many popular pilgrimage centres, as for example that of the Lord Ayappan at Sabrimalla in Kerala.

The question may be asked - is this right or wrong? To whom does the holy place ultimately belong? Such questions can never be settled by a secular law court. An understanding can only be generated within a process of religious dialogue itself. The essential question is - does any religion have a right to possess a holy place? Does Jerusalem belong to the Jews, or Rome to the Christians? Is Varanasi only to be seen as a Hindu holy place? What about the Buddhists, and the Muslims who also have their place on the banks of the River Ganges? Only when different faiths can live in peace in the same holy place, can we hope for a real and genuine inter-faith dialogue.

All faiths have this at their foundation - a rootedness in the soil. When Christians want to discover their rootedness in the Indian soil, where are they to find it except in the Holy places of India? When I visit a holy place in India, I can feel that primordial sense of belonging. I cannot "possess" the earth, I can only belong to it. The holy place possesses the hearts of those who feel the presence of a divine hierophany in that place, here and now. For me, among the thronging pilgrims at the ghats on the river Ganges, Christ is also present. Not that Christians have any right to claim these holy places-but they cannot also be excluded. Our ancestors also worshipped here. In that sense we are Hindu Christians. When Jesus went up to Jerusalem he was fulfilling a primordial impulse of the Jewish people. Long before Jesus, even Abraham had come here, to be blessed by a mysterious king Melchisedech, who was not a Jew, but who was king of Jerusalem. The sources of this sacred city reach far back beyond memory.

It is imperative, I feel, that as believers-Hindu, Buddhist, Christian, Muslim - we first acknowledge the sacredness of the earth, and the fact that we all belong to this earth, and all want to celebrate its holiness. Then our desire to build temples will not lead to bitter strife. For finally, as Jesus said to the Samaritan woman - "Woman believe me, the hour is coming, when neither on this mountain nor in Jerusalem will you worship the father, ...the hour is coming, and now is, when true worshippers will worship the father in spirit and truth, for such the father seeks to worship him. God is spirit and those who worship him must worship in spirit and truth" (John 4:21ff).

This certainly is the high point of every spiritual tradition-the belief that ultimately what gives meaning to the holy place is not the visible tangible structure but a spirit based on the worship of an inner truth. Unless spirituality can transcend the desire to possess, all devotion can only lead to a psychic dependency which is the opposite of true inner freedom. All the great prophetic traditions have for this very reason been critical of temple worship. But that does not mean that they have rejected a sense of the sacredness of the earth. The holy place is the sacrament of the earth but it can never enslave the human heart. Every one of us is a fragment of the earth and therefore, every one of us is ultimately holy. As Kabir was to insist-the Masjid or Mandir are only "signs" of what is common to us all, the blessing of life which God has given to all creatures. 


\section{Viewpoints}

In this realization we must learn to share that blessing. 